\title{
Variation in Primary Production In Relation to Physico- chemical parameters of Kadwai Reservoir, Ratnagiri, Maharashtra, India.
}

\author{
RAHUL PRALHAD RATHOD ${ }^{1}$, BALASAHEB R. CHAVAN² and RAGHUVENDRA K. PAI ${ }^{3}$
}

'Postgraduate Student, Dept. of Aquaculture, College of Fisheries, Ratnagiri, India

${ }^{2}$ Associate Research Officers, Marine Biological Research Station, Ratnagiri, India

${ }^{3}$ Associate Dean, College of Fisheries, Ratnagiri, India

http://dx.doi.org/10.12944/CWE.11.1.28

(Received: February 25, 2016; Accepted: April 04, 2016)

\begin{abstract}
The present study has been carried out to study the status of primary productivity in relation to physiochemical parameters of the Kadwai reservoir of Ratnagiri district, Maharashtra. The primary productivity was determined by estimating gross and net primary productivity. The experiment was conducted during the monsoon and post monsoon seasons from $1^{\text {st }}$ June to $30^{\text {th }}$ Nov 2015 to know the effect of organic run off on primary production of Kadwai reservoir. The physiochemical parameters such as temperature, $\mathrm{pH}$, dissolved oxygen, total hardness, total alkalinity and transparency ranged from $27^{\circ} \mathrm{C}-30.5^{\circ} \mathrm{C}, 7.5-8.6,3.2-7.0 \mathrm{mg} / \mathrm{l}, 46-75 \mathrm{mg} / \mathrm{l}, 56-95 \mathrm{mg} / \mathrm{l}$, and $118-130 \mathrm{~cm}$, respectively. The gross primary productivity (GPP) during monsoon was $0.07-0.11 \mathrm{gC} / \mathrm{m}^{3} / \mathrm{hr}$ in June, July and August 2015, respectively, which was very low, whereas GPP were increased during post monsoon season. The values were recorded as $0.12-0.48 \mathrm{gC} / \mathrm{m}^{3} / \mathrm{hr}$ in the months of September, October, and November 2015, respectively. The results indicated that during monsoon season, organic load is coming along with water in to the reservoir, but phytoplankton growth is minimum due to the heavy rain and flushing rate were high from the downstream of the reservoir. During post monsoon, primary productivity was increased. The results indicate that Kadwai reservoir is more productive during post monsoon season suitable for stocking fish seed.
\end{abstract}

Keyword: "Primary productivity", "GPP”, "NPP”, "Community respiration”, "Kadavai reservoir".

\section{INTRODUCTION}

Primary production refers to the amount of organic matter made from inorganic material through the process of photosynthesis ${ }^{1}$. Primary producers are organisms able to use inorganic nutrients through the process of photosynthesis to build organic matter. Thus, to grow primary producers need essential nutrients; nitrogen, phosphorus, magnesium, calcium, iron, zinc etc. in sufficient amount ${ }^{2}$.

Primary production of reservoir helps to understand the tropic status and to assess the fish production potential of aquatic ecosystem ${ }^{3}$. To estimate the total biological activity of reservoir it is necessary to determine the primary production. The study of primary production in lakes and reservoir are essential to understand both water quality and fisheries ${ }^{4}$. Primary production is influenced by biotic as well as abiotic factors. Enrichment of nutrient and dry matter in the reservoir affects diversity of plankton and physico-chemical characters of water ${ }^{5}$.

High and low productivity values of water bodies due to the low nutrient content in the water ${ }^{6}$. Several factors, solar radiation, nutrient content, 
high seasonal rate of in water level and high flushing rate are influenced the rate of primary production in freshwater ${ }^{7}$.

The Konkan region of Maharashtra falls under high rainfall zone and large reservoirs area are available for culture based capture fish production ${ }^{8}$. In Konkan region of coastal Maharashtra encircles Kadwai reservoir. As the chief food of the people in the Konkan region is rice and fish, therefore it enhances the need of freshwater aquaculture in this vicinity. To achieve the need of food as cheap source of animal's protein from fish, culture based capture fisheries practices could be initiated in Kadwai reservoir. But prior to commence commercial practices of fisheries, it is essential to estimate primary productivity in relation to physico-chemical parameters of Kadwai reservoir. Therefore, the present study was carried out to measure the changes of primary productivity of Kadwai reservoir in monsoon and post monsoon season for enhancing aquaculture practices, for possible utilization and sustainable management of the Kadwai reservoir.

\section{MATERIALS AND METHODS}

\section{Study Area}

Kadwai reservoir, located about $3 \mathrm{~km}$ away from the Kadwai village, Tal. Sangameshwar, Dist. Ratnagiri. It is formed by constructing a stonework dam across the Kadwai basin in the year 1982 at the Latitude 17R" 16' 55.4" N and Longitude 73R" 33' 52.4" E (Fig. 1). The total area of Kadwai reservoir is 14 hectors and water spread area is 22 hector and average water depth is about $11.75 \mathrm{~m}$. This reservoir is underutilized in fisheries point of view.

\section{Analysis of Primary Productivity and Physico- chemical parameters}

The present study was carried out from $1^{\text {st }}$ June 2015 to $30^{\text {th }}$ Nov 2015 for 180 days period to analyze the primary productivity of Kadwai reservoir of Ratnagiri district, Maharashtra. The primary productivity was estimated by 'Light and dark bottle' method on fortnightly basis ${ }^{9}$. The physicchemical parameters such as temperature, $\mathrm{pH}$, dissolved oxygen, total alkalinity, total hardness and transparency were analyzed fortnightly. The gross and net primary productivity was determined along with community respiration of Kadwai reservoir. The observed gross primary productivity (GPP), net primary productivity (NPP), and community respiration $(\mathrm{CR})^{10}$. The primary productivity has been expressed as gross primary productivity (GPP), Net primary productivity (NPP), and community respiration $(\mathrm{CR})$.

\section{RESULT AND DISCUSSION}

In the present investigation the physicochemical parameters such as temperature, $\mathrm{pH}$, dissolved oxygen, total alkalinity, total hardness and transparency were slightly changed in monsoon and post monsoon season. The temperature, $\mathrm{pH}$, dissolved oxygen, total alkalinity, total hardness and transparency values were ranged from $27^{\circ} \mathrm{C}$ $29^{\circ} \mathrm{C}, 7.5-7.8,3.2-4.8 \mathrm{mg} / \mathrm{l}, 76-95 \mathrm{mg} / \mathrm{l}, 53-75 \mathrm{mg} / \mathrm{l}$, and $125-130 \mathrm{~cm}$, respectively, in monsoon season. Whereas in post monsoon season the values ranged from $30^{\circ} \mathrm{C}-30.5^{\circ} \mathrm{C}, 7.5-8.6,4.4-7.0 \mathrm{mg} / \mathrm{l}, 56-63 \mathrm{mg} / \mathrm{l}$, 46-53 mg/l, and $118-124 \mathrm{~cm}$, respectively. Variation of physico-chemical parameters are shown in Fig.2.

The GPP, NPP, and CR of the reservoir water are varied in month-wise and season-wise. The values of GPP, NPP, and CR were ranged from 0.07-0.11, 0.02-0.10, and 0.02-0.09 gC/m $3 /$ $\mathrm{hr}$, respectively, in the monsoon season, whereas in post monsoon season the values were varied from 0.12-0.48, 0.09-0.21, and 0.02-0.36 gC/m $\mathrm{hr}$, respectively. The highest GPP was found in months of October and November and lowest was found in the month of June, July, and August. The highest values of NPP were found in the month of October and November and lowest was June, July, and August. The community respiration (CR) was highest in the month of October and November and lowest in the month June, July, and August shown in Fig. 3

The GPP and NPP were highest in the post monsoon season. The temperature is raised in the month of September and October, which enhance the release of nutrients from organic sediments through decomposition and it provide favourable conditions for primary production. Sultan et al. reported that temperature, solar radiation and available nutrients 
may be important limiting factors for primary production and contributing to seasonal variation in aquatic ecosystem ${ }^{11}$.

The value of planktonic community respiration is deducting net primary productivity from gross primary productivity and converted into $\mathrm{CO}_{2}$ release ${ }^{10}$ in our study the maximum value community respiration of $0.36 \mathrm{mgC} / \mathrm{L} / \mathrm{hr}$ was recorded in October and November and minimum value of 0.036 $\mathrm{mgC} / \mathrm{L} / \mathrm{hr}$ in monsoon. Higher values of planktonic community respiration during September may be due the effect of effluent from agriculture runoff coming into the reservoir that enhancing the biological activities of microbial organism due to the deposition of organic matter into the reservoir and therefore, fortnightly variations were observed during study due to these effects in primary productivity of Kadwai reservoir. Patil et al. in Ajara reservoir, noticed that the seasonal changes in primary productivity were minimum ranges during the monsoon and maximum in summer season ${ }^{5}$. The primary productivity data were collected during monsoon and post monsoon season. Koli et al. observed that gross primary productivity (GPP) values ranged between 1.93 and $6.24 \mathrm{gC} / \mathrm{m}^{3} /$ day, net primary productivity (NPP) ranged between 0.72 and $499 \mathrm{gC} / \mathrm{m}^{3} /$ day and community respiration (CR) ranged from 0.26 to 3.6

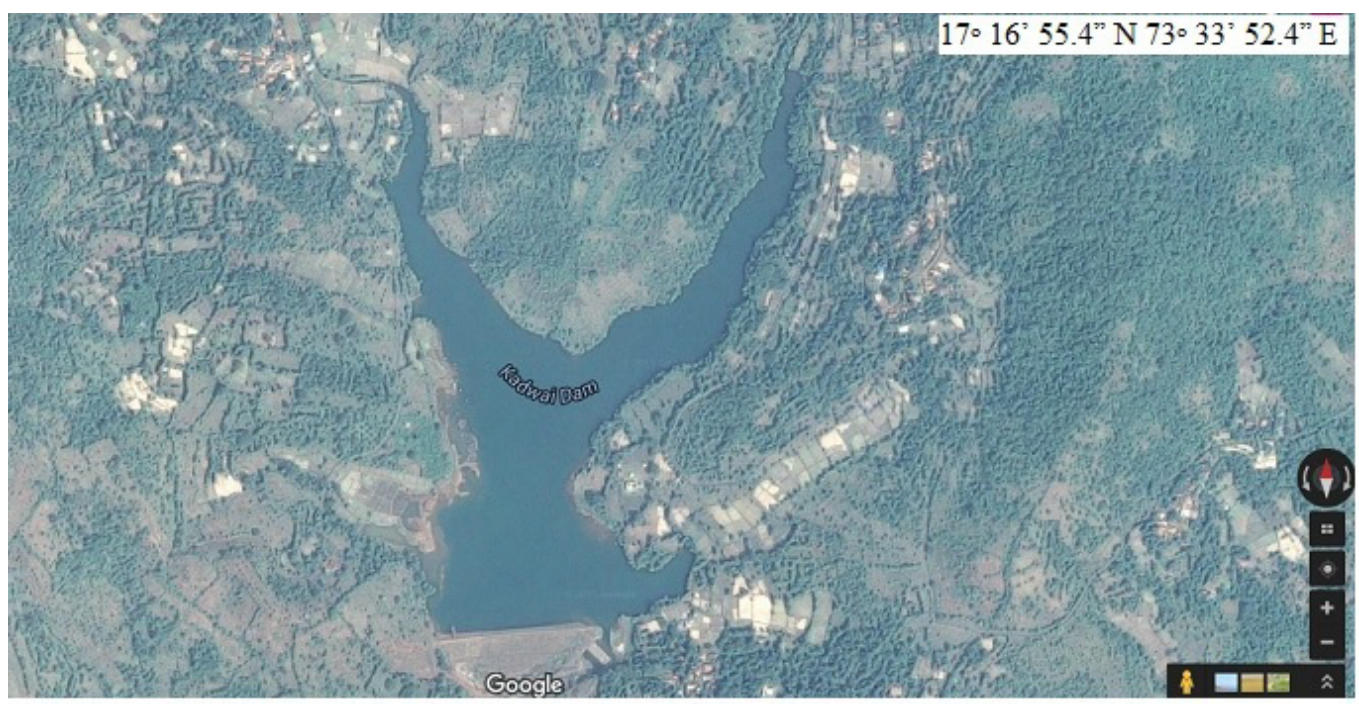

Fig. 1: Satellite location of Kadwai reservoir, Sangmeshwar, Ratnagiri, Maharashtra

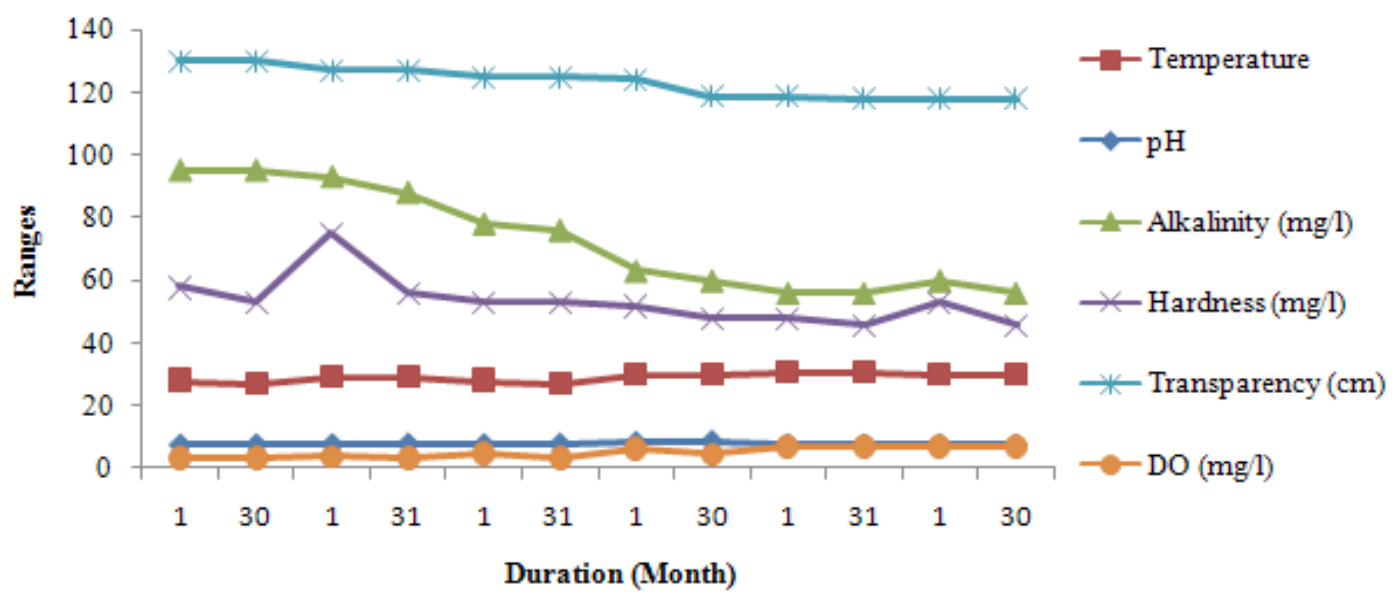

Fig. 2: Physico-chemical parameters of Kadwai reservoir, $1^{\text {st }}$ June 2015 - 30 $0^{\text {th }}$ Nov 2015 


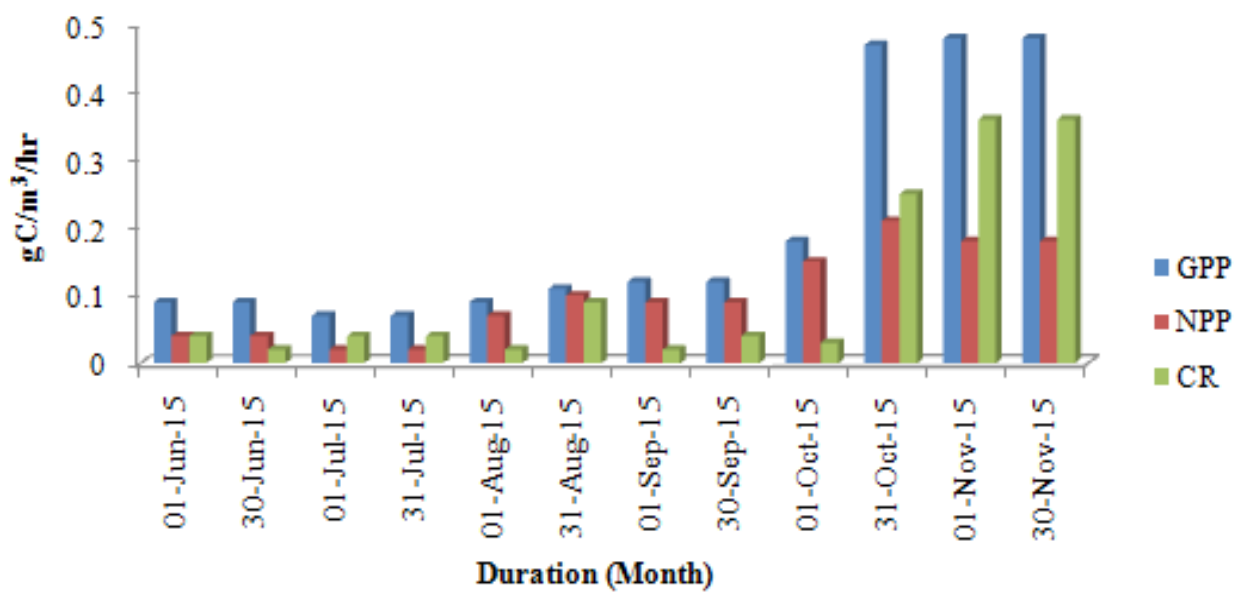

Fig. 3: Variations in (GPP), (NPP) and (CR) in Kadwai reservoir

$\mathrm{gC} / \mathrm{m}^{3} /$ day, during September 2007 to August $2008^{12}$. The seasonal variations in GPP lower in monsoon $0.66 \pm 0.17$ and higher in summer $1.05 \pm 0.15 \mathrm{gC} /$ $\mathrm{m}^{3} / \mathrm{hr}$, NPP noticed $0.60 \pm 0.17$ in monsoon and $1.45 \pm 0.23 \mathrm{gC} / \mathrm{m}^{3} / \mathrm{hr}$ in summer and CR showed minimum in monsoon $0.06 \pm 0.01$, higher in winter $020 \pm 0.07 \mathrm{gC} / \mathrm{m}^{3} / \mathrm{hr}$ in Mombatta lake ${ }^{13}$.

\section{CONCLUSION}

With the results, we can conclude that the Kadwai reservoir is productive during post monsoon season and the primary production were influence by the organic runoff from agriculture and nutrient coming along with the rain water during monsoon play the major role in the development of primary productivity and is suitable for stocking fish seed in the post monsoon for development of culture based capture fishery.

\section{ACKNOWLEDGEMENT}

The authors are thankful to the authorities of Dr. Balasaheb Sawant Konkan Agriculture University, Dapoli, Ratnagiri for providing necessary facilities to carry out present research work. The author also thankful to the funding agency "Rajiv Gandhi Science and Technology Commission" (RGSTC), Mumbai for providing the required funds for implement the cage culture project in the Kadwai reservoir.

\section{REFERENCES}

1. Babar, H.T., and Raje, G.B., Primary productivity study of Morawane dam in Ratnagiri district of Maharashtra, India. Journal of Global Bioscinces, 4(2): 14301438 (2015).

2. Fatima, K., Rajashekhar, M., Gayatri, Vijaykumar, M., Ratandeep, and Mahesh, B., Primary productivity in inland reservoir, Gulbarga district, Karnataka, South India. Journal of Ecology and Environmental Sciences, 2(1): 11-14 (2011).

3. Melack, J. M., Primary production and fish yield in tropical lakes. Trans. Amer Fish. Soc. 105(5): 575-580 (1976).
4. Wondie, A., Mengistu, S., Vijverberg, J., and Degen, E., Seasonal variation in primary production of a large high altitude tropical lake: effects of nutrient availability and water transparency. Auat Ecol, 41:195-207 (2007).

5. Patil, S. R., Patil, S. S., and Sathe, T. V., Seasonal changes in primary productivity at water reservoir of Ajara tahsil from Kolhapur district, Maharashtra, India. European Academic Research, 2 (12): 15824-15830 (2015).

6. Radheshyam, B. B., Satpathy, B. N., Singh, S. K., Sankar, J. P. V., Kumar, K., and Dutta, B. R., Utilization of small backyard pond for 
fish culture in rural area- A new perspective. J. Res. 1: 129-139 (1988).

7. Adeniji, F. L. A., Limnology and biological production in the pelagic zone of Jebba lake, Nigeria. Ph.D Thesis, University of Ibadan, Nigeria. 293 pp (1990).

8. Mane, M. S., Ayare, B. L., Kubal, D. S., Suvane, A. B., and Patil, H. K., Development of rainfall intensity nomograph for Dapoli of Konkan region of Mahrashtra, India. Internat. J. Sci. 3 (2): 22-25 (2007).

9. Garder, T., and Gran, H.H., Production of plankton in Oslo Fjord. Rap. Proc. Verb. Cons. Prem. Int. Explor. Mer., 42: 9-48 (1927).

10. Boyd, C.E., Water quality in warm water fish ponds. Auburn University, Alabama, USA,
1-359 pp (1981).

11. Sultan, S., Chauhan, M., and Sharma, V. I., Physiochemical status and primary productivity of Pahuj reservoir, Uttar Pradesh. J. Inland Fish. Soc. India, 35: 73-80 (2003).

12. Koli, V. K., and Ranga, M. M., Physicochemical status and primary productivity of Ana sagar lake, Ajmer, Rajasthan. Universal Journal of Environmental Research and Technology, 1(3): 286-292 (2011).

13. Sontakke, G. K., Mokashe, S. S., Seasonal variation in primary productivity of two freshwater lakes of Aurangabad district, Maharashtra, India. International Journal of Fauna and Biological Studies, 1(6): 7-10 (2014). 